Personality in sport: A comprehensive review

This is an Author's Original Manuscript of an article published by Taylor \& Francis in International Review of Sport and Exercise Psychology in 2013 available online at http://www.tandfonline.com/10.1080/1750984X.2013.769614

Allen, M. S., Greenlees, I., \& Jones, M. V. (2013). Personality in sport: A comprehensive review. International Review of Sport and Exercise Psychology, 6,184-208. 


\begin{abstract}
This review addresses personality in organised sport. We describe the extant literature that has explored personality effects on athletic success and population based differences before hypothesising how sport participation may contribute to personality development. We then outline the role of personality in athletic interactions and group processes before considering the practical applications of personality research and avenues for future study. Our review shows that personality is an important determinant of long-term success in sport and identifies clear personality differences between individuals that participate in organised sport and individuals that do not participate in organised sport. We also observe important personality differences between subsamples of athletes and outline the contribution of personality to intragroup relationships and team effectiveness in team sport. The interaction of genetic and environmental influences is presented as a promising avenue of inquiry that can strengthen our understanding of personality effects on sport and exercise participation and athletic success. We conclude by outlining implications for applied sport psychology.
\end{abstract}

Keywords: five factor model, developmental changes, behaviour genetics, social interaction, peak performance 


\section{Personality in sport: A comprehensive review}

Research on personality and its relationship to important personal, interpersonal, and social behaviours is as popular today as at any point in its history (Funder, 2001; Funder \& Fast, 2010). The predictive power of personality is no more apparent than in reviews of studies documenting associations between personality and important life outcomes (Hampson, 2012; Ozer \& Benet-Martínez, 2006). They show that personality traits can predict outcomes for individuals (e.g. happiness, health), dyads (e.g. relationship commitment), groups (e.g. team cohesion), and society (e.g. criminal behaviour). With such a strong foundation of research evidence it is surprising that personality traits and their contribution to athletic success has often been viewed in rather cynical and pessimistic manner. Despite the historical impetus behind personality research in sport, Vealey (2002) observed that "many researchers ... believe that sport personality research has yielded no useful findings" (p. 71) while Gill and Williams (2008) comment that "most scholars see little value in global personality measures" (p. 46). In this article we challenge these conventional opinions and following a critical review of the extant literature arrive at rather different conclusions to most narrative reviews on this topic. Moreover, we show that personality has much predictive utility in organised sport and can contribute to the development of applied interventions in various athletic contexts. Perhaps more importantly, we offer a number of possibilities for the progression and expansion of personality research in this field.

\section{Overview of personality in sport}

Since its integration into Coleman Griffith's teachings on the psychology of sport and performance (Griffith, 1926, 1930) personality has remained a core element on most taught sport and exercise psychology programmes and psychologists have continued their endeavour to understand the personality of the successful athlete. When the first sport and exercise 
psychology laboratories were developed during the early part of the $20^{\text {th }}$ century, habit $^{1}$ was identified as a key factor influencing development and success in sport (Griffith, 1930). The 1930s to 1960s have been described as a rather stagnated period for sport and exercise psychology research (Weinberg \& Gould, 2011) but one area that continued to prosper and dominated the field throughout this period was personality research. This included descriptive reports of personality profiles of successful athletes (Thune, 1949), developmental changes in personality and achievement in physical education (Sperling, 1942), personality differences between athletes and non-athletes (Carter \& Shannon, 1940), descriptive personality reports of female athletes (Fleming, 1934), personality differences between athletes competing in different sports (Booth, 1958) or different physical activity groups (Flanagan, 1951), personality predictors of sport and exercise participation (Fauqier, 1940), and personality determinants of performance outcomes (La Place, 1954) and performance quality (Merriman, 1960).

From the 1960s onward research inquiry increased exponentially and it has been estimated that over 1000 studies were published during the 1960s and 1970s alone on personality in sport (Fisher, 1984). Interestingly, just as contemporary theories of personality began to emerge during the turn of the 1990s (Digman, 1989; John, 1990; McCrae \& Costa, 1987), transforming the field and strengthening understanding of personality trait structure, research inquiry in competitive sport came to a rather abrupt end. Over the past twenty years only sporadic attempts have been made to investigate personality in athletic populations and there has been very little progress towards answering some of the fundamental questions raised in the early part of the $20^{\text {th }}$ century. This is evident in recent edited works that have excluded a chapter on personality, included in earlier editions, presumably because of the lack of progress in this field (e.g. Horn, 2008; Tennenbaum \& Eklund, 2007).

\footnotetext{
${ }^{1}$ The term personality was coined later by Allport (1937) to reflect what psychologists and laypeople currently mean by the term.
} 
The decline of personality research is difficult to explain but it is important to speculate on how a field that dominated for so many years could suddenly fall out of favour

with researchers. It has been suggested that researchers did not so much abandon the topic of personality, but rather, shifted their interests towards more specific foci such as trait anxiety, optimism, hardiness, and mental toughness (Vanden Auweele, Nys, Rzewnicki, \& Van Mele, 2001). These topics have been investigated extensively in recent years (see, for example, Gucciardi \& Gordon, 2011; O’Rourke, Smith, Smoll, \& Cumming, 2011) and researchers have generally used context (sport) specific measures to understand how athlete behaviour generalises across competitions. Although an athlete's tendency to experience anxiety (or show resilience, or be optimistic) across sport competitions may provide some insight into their personality, such domain specific measures provide little information about the overall contribution of traits to athlete and team behaviour. This article is concerned with deep-level composition variables and therefore excludes coverage of domain-specific and specialised topics. We also exclude research on personality in exercise and health settings and readers are referred to the comprehensive review by Rhodes and Pfaeffli (2012) for an overview of this area.

\section{Personality theory and assessment}

Personality can be defined as "psychological qualities that contribute to an individual's enduring and distinctive patterns of feeling, thinking and behaving" (Pervin \& Cervone, 2010, p. 8). Personality theory has an extensive history and comprehensive accounts of personality structure can be found in the works of Hippocrates (460-370 BC), Galen (AD 129-199) and many other natural philosophers. The modern era of personality (scientific) research continues to adopt the concept of personality "dimensions" and the hierarchical approach to personality structure, initially proposed by Allport $(1927,1937)$, has 
been incorporated into most modern theories of personality (see Barenbaum \& Winter, 2008, for a historical overview of personality theory).

There are two main approaches to the assessment of personality: type based assessments (that categorise an individual as one type or another) and trait based assessments (that position an individual on a series of bipolar linear continua). Although type based assessments are still used in personality research (most often in clinical settings to identify people with particular personality disorders) they have received considerable criticism from psychometric researchers (cf. Asendorpf, 2003; Pittenger, 2004) as personality test scores consistently produce a normal distribution curve. This fails to support the concept of "type" (e.g. introvert or extravert) as most people fall on the middle of the scale (McCrae \& Costa, 1989). Trait based assessments offer an accurate location for personality test scores on a continuous probability distribution and after many decades of research the field has achieved a consensus on a general taxonomy of personality traits: The so-called "big five" personality dimensions.

The big five personality dimensions do not represent a particular theoretical perspective but were derived from analyses of the natural language and describe the most basic and general dimensions upon which persons are typically perceived to differ (John, Naumann, \& Soto, 2008). Perhaps the most significant advance in this area was the development of the five-factor model/five-factor theory of personality (McCrae \& John, 1992; McCrae \& Costa, 2008). The five-factor model adopts the basic tenets of trait theory (e.g. cross-situational consistency) and contends that the five personality dimensions, named extraversion, neuroticism, openness, agreeableness and conscientiousness, each encompass a number of more specific traits (termed facets). For example, the neuroticism dimension assesses the degree to which individuals are prone to emotional instability and includes facets of anxiety, hostility, depression, self-consciousness, impulsiveness and vulnerability. The 
other dimensions, extraversion (that assesses the quantity and intensity of interpersonal interactions), openness (that assesses individuals' tendency to seek out new experiences) agreeableness (that assesses individuals' concern for cooperation and social harmony) and conscientiousness (that assesses organisation and goal-directed behaviour) also incorporate a number of more specific facets (Costa \& McCrae, 1992). Although not without its critics (see, for example, Block, 2010), the five-factor model has become the most widely accepted model of personality trait structure.

Comprehensive meta-analyses have demonstrated that the five personality dimensions are associated with a number of personal, interpersonal, and social behaviours including, but not limited to, leadership (Bono \& Judge, 2004; Judge, Bono, Ilies, \& Gerhardt, 2002), motivation (Judge \& Ilies, 2002), coping strategies (Connor-Smith \& Flachsbart, 2007; also see Carver \& Connor-Smith, 2010), work-family conflict (Michel, Clark, \& Jaramillo, 2011), alcohol involvement (Malouff, Thorsteinsson, Rooke, \& Schutte, 2007), smoking involvement (Malouff, Thorsteinsson, \& Schutte, 2006), relationship satisfaction (Malouff, Thorsteinsson, Schutte, Bhullar, \& Rooke, 2010), burnout (Alarcon, Eschleman, \& Bowling, 2009), job satisfaction (Judge, Heller, \& Mount, 2002), job performance (Barrick \& Mount, 1991; Hurtz \& Donovan, 2000; Oh, Wang, \& Mount, 2011), academic performance (Poropat, 2009; also see Poropat, 2011), and team performance (Bell, 2007; Peeters, Van Tuijl, Rutte, \& Reymen, 2006a). Unfortunately, sport based research has not progressed to the level of systematic research synthesis with only a handful of studies having investigated the relationship between the five personality dimensions and performance in sport. Nevertheless, important trends can be observed in the extant literature that provide valuable insight into personality effects on athletic success. 
There are good reasons to expect personality to predict athletic success based on the theoretical predictions that govern associations between personality and academic or organisational success. Performance in both work and academia is determined by factors related to capacity and willingness to perform and these are governed by personality (Poropat, 2009). In sport settings, success is also determined, at least in part, by an athlete's capacity (e.g., ability to cope with pressure) and willingness to perform (e.g. effort, perseverance) and it is tempting to assume that associations between personality and sport performance should mirror those observed in academic and organisational settings. However, a number of critical differences between these domains (e.g. competitive sport is an optional endeavour whereas academia and employment are compulsory) may prevent findings transferring directly across contexts. Thus, the similarities between these domains might suggest similar associations with personality, but these similarities are not sufficient to assume this is the case.

The relationship between personality and sport performance has been investigated using a variety of research designs. One particular approach has been to compare personality test scores of athletes competing at a lower performance level with those competing at a higher performance level. Although these types of research designs cannot exclude the possibility that other confounding variables are contributing to performance differences, they do offer valuable information on whether personality is associated with long-term or career success in sport. Findings from small sample studies have generally shown few personality differences between elite and recreational level athletes (Davis \& Mogk, 1994; Frazier, 1987; Gat \& McWhirter, 1998). However, large sample studies have demonstrated important differences that point towards elite athletes being more extraverted and emotionally stable than recreational level athletes (Egloff \& Gruhn, 1996; Kircaldy, 1982a; Williams \& Parkin, 1980). More recently, athletes competing in national or international competitions have been 
found to have lower levels of neuroticism and higher levels of conscientiousness and agreeableness than athletes competing in club or regional competitions (Allen, Greenlees, \& Jones, 2011).

Other research has explored performance differences by comparing personality profiles of starting athletes with non-starting athletes and by correlating personality test scores with competition performance. Generally, regular starters and non-regular starters have not shown any meaningful differences in personality characteristics (Evans \& Quarterman, 1983; Garland \& Barry, 1990) and personality measures have not been particularly successful in predicting single-match success (Morgan, 1968; Rogulj, Nazor, Srhoj, \& Božin, 2006). Two further approaches include studies correlating personality test scores with season-long performance indicators and studies comparing athletes who progress to professional level with those that do not progress to professional level. Small but significant effects have been observed between personality and season-long performance indicators (Piedmont, Hill, \& Blanco, 1999; Sindik, 2010) whereas large effects have been observed between personality and progression to an elite level of competition (Aidman, 2007; Gee, Marshall, \& King, 2010; Martin, Malone, \& Hilyer, 2011; Morgan \& Johnson, 1978). For example, the study by Aidman (2007) found that personality test scores of elite junior football players could predict whether they had progressed to professional level seven years later. Although more critical tests are required, these findings suggest that long-term success in sport is partly a function of personality whereas short-term success is unrelated to personality.

It is not surprising that personality test scores have struggled to predict short-term (single-game) success since a single moment of bad luck, an unexpected event, or a poor decision by an official can alter the outcome of a competition dramatically. Therefore, in order to identify whether personality has any meaningful short-term effects researchers have 
begun to explore how personality dimensions relate to behaviours associated with success in sport. For instance, a recent study of British gymnasts demonstrated that conscientiousness was positively associated with athletes' quality of preparation in the lead up to competition and emotional stability was positively associated with effective coping during competition (Woodman, Zourbanos, Hardy, Beattie, \& McQuillan, 2010). Other research has explored the effect of personality on psychological states such as aggressiveness (Trninić, Baranĉić, \& Nazor, 2008) and coping functions (Allen, Frings, \& Hunter, 2012; Allen et al., 2011; Kaiseler, Polman, \& Nicholls, 2012). These studies show that athletes with low levels of agreeableness, extraversion, and/or emotional stability are more prone to aggressive behaviours, athletes with low levels of openness and/or emotional stability are more prone to using avoidance coping strategies, and athletes with high levels of conscientiousness, extraversion, and/or emotional stability are more prone to using problem-focused coping strategies.

In addition to the direct effects observed between personality and outcomes, important moderating effects have also been identified in athletic samples. Indeed, the degree to which sport performance is influenced by the presence of an audience (Graydon \& Murphy, 1995) and the degree to which emotions have positive or negative effects on sport performance (Woodman et al., 2009) have been shown to be moderated by extraversion. Specifically, extraverted athletes appear to outperform introverted athletes when an audience is present but not when there is no audience present and anger appears to have a positive effect on sport performance but only for athletes with high levels of extraversion. These emerging findings provide an alternative approach to researching and understanding personality effects in sport and further research into the moderating role of personality would be particularly valuable to practicing sport psychologists designing interventions that target the psychological constructs under investigation. Collectively, the available data show that personality has an important 
role in sport performance but further research is required to provide more detailed information about effect sizes (for each of the five dimensions) and how personality relates to other important factors associated with success in sport (e.g. burnout, leadership). Because personality has the potential to moderate important relationships in sport it is important to understand how personality differs across discrete athletic populations so that practitioners can tailor their interventions towards the particular client or context in which they are operating.

\section{Population based differences}

For a long time researchers have contemplated whether there is such a thing as an athletic personality (Carter \& Shannon, 1940; Thune, 1949). This remains an important question as it can provide valuable information on whether important relationships (or successful interventions) observed in other (non-athletic) domains remain valid in athletic samples. There is good evidence to suggest that personality is associated with participation in regular exercise (Rhodes \& Pfaeffli, 2012; Rhodes \& Smith, 2006) and personality differences can also be found between people that participate in organised sport and people that do not participate in organised sport. Specifically, athletes consistently demonstrate higher levels of extraversion than non-athletes (Colley, Roberts, \& Chipps, 1985; Egloff \& Gruhn, 1996; Paunonen, 2003) and some studies have observed that (in addition to being more extraverted) athletes have greater levels of emotional stability (Egan \& Stelmack, 2003; Kirkcaldy, 1982a; McKelvie, Lemieux, \& Stout, 2003; Newcombe \& Boyle, 1995) and are more open to new experiences (Hughes, Case, Stuempfle, \& Evans, 2003; Kajtna, Tušak, Barić, \& Burnik, 2004).

In the comprehensive meta-analysis by Rhodes and Smith (2006) it was shown that physical activity involvement has a medium positive association with extraversion $(r=.23)$, a medium positive association with conscientiousness $(r=.20)$, and a small negative 
association with neuroticism $(r=-.11)$. It is tempting to assume that the dimensions of personality that predict participation in organised sport should mirror those that predict participation in regular exercise. However findings may not transfer directly across contexts. This is because the motives that drive people towards exercise (e.g. health) can differ from those that drive people towards organised sport (e.g. competition). In particular, we might expect openness to have a greater role in predicting participation in organised sport (since openness reflects a tendency to seek out new and exciting experiences) and conscientiousness to have a greater role in predicting participation in regular exercise (since conscientiousness reflects a tendency towards careful and compulsive behaviour). These possibilities have yet to be tested empirically, but findings cannot be assumed to transfer directly across contexts and further research is needed to verify the role of conscientiousness, openness, and neuroticism in discriminating between exercisers, sport participants, and non-participants.

Another common objective in sport-based personality research is to identify whether personality test scores can discriminate between athletes participating in different sports . For the most part, personality test scores have never been particularly successful in separating athletes competing in one sport from athletes competing in another sport (Johnson \& Morgan, 1981; Lackie, 1962; O’Sullivan, Zuckerman, \& Kraft, 1998). However, important personality differences have been observed between athletes participating in different types of sport (Dowd \& Innes, 1981; Geron, Furst, \& Rotstein, 1986; Peterson, Webber, \& Trousdale, 1967; Schurr, Ashley, \& Joy, 1977). These studies have consistently demonstrated that team sport athletes have different personality characteristics to individual sport athletes most often differing on facets of extraversion (team sport athletes show greater levels of extraversion). Population-based differences have also featured in a series of recent studies exploring a greater range of personality dimensions. Specifically, team sport athletes show higher levels of extraversion and lower levels of conscientiousness than individual sport athletes (Allen et 
al., 2011; Nia \& Besharat, 2010; Eagleton, McKelvie, \& deMan, 2007) and athletes in high risk sports show higher levels of extraversion and lower levels of conscientiousness than athletes in low risk sports (Castanier, Le Scanff, \& Woodman, 2010; Coetzee, 2010; Rhea \& Martin, 2010; Tok, 2011). These findings support the contention that personality test scores can discriminate between discrete athletic populations and that extraversion and conscientiousness in particular show the greatest variability between samples.

In team sports it is also possible that athletes differ in personality relative to the position or role in which they perform. To date, only a handful of studies have explored personality differences across playing positions. Often, research has focused on specific athlete behaviours, rather than personality characteristics, and these small sample studies have observed that athletes in offensive positions have better anxiety control (Cox \& Yoo, 1995) and are more responsible (Greenwood \& Simpson, 1994) than athletes in defensive positions. Only three studies have directly explored differences in personality across playing positions. There is some evidence that athletes in more offensive positions are more extraverted than athletes in more defensive positions (Kirkcaldy, 1982b; Schurr, Ruble, Nisbet, \& Wallace, 1984). More recent research, however, has reported that offensive, defensive, and goaltending athletes do not differ substantially on any of the five personality dimensions (Cameron, Cameron, Dithurbide, \& Lalonde, 2012). It is not unreasonable to expect personality differences between playing positions as different positions often require different behaviours that may be more or less suited to persons with particular personality characteristics. Currently, however, the evidence base is not sufficient to draw any reasonable conclusions about those differences and personality variation across playing positions remains an area for further research.

Outside of sport, a number of meta-analytic and large sample studies have observed personality differences between men and women (Costa, Terracciano, \& McCrae, 2001; 
Feingold, 1994; Schmitt, Realo, Voracek, \& Allik, 2008). The general finding of these investigations is that, compared with men, women tend to have higher levels of neuroticism, extraversion, agreeableness and conscientiousness. It has been suggested that in athletic populations women are likely to display personality characteristics closer to those of men than non-athletic women (Fleming, 1934; Williams, 1980). Although researchers have not explored this hypothesis directly, a number of investigations have compared personality test scores of men and women participating in organised sport. In one study of adolescent athletes, it was found that girls were more extraverted and emotionally unstable than boys (Newcombe \& Boyle, 1995). Two studies in adult sport performers also found that women were more emotionally unstable than men with no observable difference on extraversion (Colley et al., 1985; Kirkcaldy, 1982a). A more recent study assessing a greater range of personality dimensions has shown that, compared with men, women have higher levels of neuroticism, agreeableness, and conscientiousness (Allen et al., 2011). Although further tests are required, these findings appear to directly mirror those observed in non-athletic populations.

Population based differences are clearly evident in the extant literature and it is likely that all five dimensions of personality have a role in discriminating between samples and subsamples of athletes. The effect sizes of each personality dimension remain unknown and these will become clearer once a more substantial body of research has accumulated and researchers are able to apply meta-analytic techniques to quantitatively synthesise study findings. Understanding these effects is of value in and of itself but perhaps a more interesting question relates to the underlying causes of these group-based differences. To speculate on the causes of athlete - non-athlete personality differences, the most obvious explanation is that people choose to take part in activities that require behaviours manifest in their personality. Sport competitions involve much communication and social interaction and 
are therefore best suited to extraverted individuals. This could also explain why athletes in team sports differ from athletes in individual sports since team sports generally involve greater levels of interdependence and social interaction (this is sometimes referred to as the gravitation hypothesis). However, it is also possible that taking part in sport, and being compelled to communicate and cooperate with others, helps to develop desirable personality characteristics such as extraversion (this is sometimes referred to as the change hypothesis). There has been little progress towards understanding the causes of these group-based differences and future longitudinal research is required to identify whether personality directly affects participation in organised sport and whether participation in sport contributes to personality development. In order to speculate on these effects it is necessary to consider the biological basis of personality and the stability of personality traits throughout the lifespan.

\section{Personality continuity and sport participation}

The traditional research focus of behavioural genetic enquiry was to estimate the magnitude of genetic and environmental influences on behaviour. The most convincing evidence for hereditary contributions to personality has come from twin, family and adoption studies. These studies have demonstrated that monozygotic (identical) twins are more similar in personality than are dizygotic (fraternal) twins (Riemann, Angleitner, \& Strelau, 1997), that adopted children are more similar in personality to their biological parents than to their adoptive parents (Loehlin, Willerman, \& Horn, 1985), and that monozygotic twins reared apart are more similar in personality than are dizygotic twins reared together (Hershberger, Plomin, \& Pedersen, 1995; Pedersen, Plomin, McClearn, \& Friberg, 1988). The hereditary contributions to human personality are now well established. Studies have repeatedly demonstrated that adult personality traits show substantial genetic contributions (in the region of $50 \%$ ), that shared environments (e.g. family income, parenting style) contribute little to no 
variance in observed traits, and therefore, that non-shared environments also have a substantial effect on personality traits (Krueger \& Johnson, 2008; Krueger, South, Johnson, \& Iacono, 2008).

Further evidence for genetic and environmental influences on personality has come from longitudinal studies. Not surprisingly, the literature points to the role of genetic factors in maintaining personality stability throughout the lifespan, and unique environmental factors acting to promote personality change (Krueger \& Johnson, 2008). Personality continuity has also been shown to increase with age. A comprehensive meta-analysis of 152 longitudinal studies showed test-retest correlation coefficients of .31 in childhood, .54 in university years, .64 at age 30, and .74 between age 50 and 70 (Roberts \& DelVecchio, 2000). These values were relatively consistent for each of the five dimensions and support the notion that personality is more variable in childhood and adolescence. More recent research has supported these findings but suggest that personality continuity may plateau at an earlier age - around early adulthood (Terracciano, McCrae, \& Costa, 2010).

Longitudinal research has also established that personality changes in predictable patterns. As people progress from adolescence through late midlife, they become more agreeable, conscientious and emotionally stable (Caspi, Roberts, \& Shiner, 2005; McAdams \& Olson, 2010). This has become known as the maturity principle and was recently demonstrated in a meta-analysis of 92 longitudinal studies exploring personality test scores across age decades (Roberts, Walton, \& Viechtbauer, 2006). It was shown that conscientiousness increases gradually throughout the lifespan, agreeableness increases gradually up to age 50 and more rapidly between age 50 and 60 before levelling off, and neuroticism decreases gradually up to age 40. Importantly, not everybody demonstrated these developmental patterns and some people have been shown to change more than others. Those individuals that show greater consistency in personality traits appear to be those who 
already display a personality profile associated with maturity - low neuroticism, and high agreeableness and conscientiousness (McAdams \& Olson, 2010). This suggests that maturational development progresses at different rates and these rates of change may be a function of the social experiences to which people are exposed.

The genetic contribution to human personality has also been explored in greater detail. One particular line of inquiry has explored associations between components of personality and common gene variations (termed polymorphisms). Two relationships have received the greatest attention from personality researchers: the association between the dopamine D4 receptor gene (DRD4) and extraversion/novelty seeking traits, and the association between the serotonin transporter gene (5-HTT) and neuroticism/anxiety related traits. Generally, the results linking individual genes with personality traits have not been overly convincing or consistently replicated (Munafò et al., 2003) and several comprehensive meta-analyses show a non-significant role for DRD4 in extraversion (Munafò, Yalcin, WillisOwen, \& Flint, 2008; Schinka, Letsch, \& Crawford, 2002) and a small but significant role for 5-HTT in neuroticism (Clarke, Flint, Attwood, \& Munafò, 2010; Munafò et al., 2009; Schinka, Busch, \& Robichaux-Keene, 2004; also see Terracciano et al., 2009). This finding may reflect the traits under investigation being polygenic, meaning that many genes (each with small effects) are involved in the expression of each personality trait (Krueger \& Johnson, 2008). A number of other candidate genes have also been implicated in personality variation (see, for example, De Moor et al., 2012; Arias et al., 2012). However, a more successful approach to understanding behaviour predispositions has been to explore geneenvironment interactions.

Models that estimate genetic and environmental influences have contributed substantially to the theoretical principles underlying personality development. Geneenvironment interactions are evident when environmental differences are shown to moderate 
the effect of genes on personality traits or when genetic differences are shown to moderate the effect of environmental differences on personality traits. For instance, boys carrying the low-activity variant of the monoamine oxidase A (MAO-A) gene have been shown to display antisocial behaviour in adolescence and early adulthood, but only if they had been subjected to severe parental maltreatment (Caspi et al., 2002). In another study, adolescents carrying the low expressing $\left(\mathrm{L}_{\mathrm{G}}\right.$ or $\left.\mathrm{S}\right)$ alleles of the serotonin transporter gene $(5-\mathrm{HTT})$ have been shown to display depressive symptoms if and only if they reported having experienced prior idiographic stress (Hankin, Jenness, Abela, \& Smolen, 2011). These are just two examples from the growing field that is beginning to uncover how gene and environmental inputs combine to create individual personalities.

At this point readers may be questioning the relevance of this discussion for organised sport. The application to sport emerges if sport participation is thought of as an environmental influence acting on personality or resulting from changes in personality and personality contributors (gene-environment interactions). For instance, researchers may wish to explore the role of sport participation on the maturity principle. Through sport participation children and adolescents are subjected to adult concepts such as organisation, discipline, fair-play, sportsmanship and teamwork that may facilitate maturational development and personality traits more commonly observed in adults (low neuroticism, and high agreeableness and conscientiousness). There may also be an important geneenvironment interaction effect in the context of sport participation facilitating maturity but only for those with particular genetic traits. Indeed, research in national level swimmers (aged 10-24 years) has demonstrated that variability in the serotonin transporter (5-HTT) gene is associated with positive psychological development in the context of sport (Golby \& Sheard, 2006). 
Researchers may also wish to explore sport participation as an outcome effect of gene-environment interactions. Using twin designs it has been established that genetic variation contributes substantially to sport and exercise participation (De Geus \& De Moor, 2011; Stubbe \& De Geus, 2009) and this may involve genes influencing, among other factors, personality (Stubbe et al., 2006). The environmental influences on sport participation are well established (Biddle, Atkin, Cavill, \& Foster, 2011) and researchers may look to explore further how personality continuity during adolescence interacts with environmental changes to affect continued participation in sport and physical activity. One possible avenue for research is to explore the dopamine receptor genes associated with both personality (Munafò et al., 2008; Noble et al., 1998) and participation in sport and physical activity (Knab \& Lightfoot, 2010; Lightfoot, 2011). Changes in personality may be directly responsible for the reduction in physical activity throughout adolescence and early adulthood, and this may help explain the gene-environment (change) effects observed in adolescent sport. A study by Stubbe, Boomsma, and De Geus (2005) observed that between ages 13 and 16 genetic factors have little effect on sport participation (between $16 \%$ and $22 \%$ ), at age 17-18 genetic factors have a slightly greater role (36\%), and after 18 years genetics largely explain individual differences in sport participation (85\%). Further studies have supported the notion that environmental factors have a greater role in adolescence and genetics a greater role in adulthood (Stubbe \& De Geus, 2009) and personality may have an important role in this developmental change.

Alongside sport participation effects, gene-environment interactions could also have an important role in sport performance. Longitudinal research has demonstrated that increases in occupational success coincide with increases in extraversion (Scollon \& Diener, 2006) and similar effects may be observed with athletic success. Moreover, the combined effects of genes and environmental influences (e.g. social support) should have the greatest 
influence on athletic success (Baker, 2007). Using twin designs it has been established that genetics contributes substantially to sport performance (Davids \& Baker, 2007; Lippi, Longo, \& Maffulli, 2010) and these include a number of genes associated with psychological aptitude (Lippi et al., 2010). In particular, variability in the serotonin transporter (5-HTT) gene has been associated with hostility, irritability and negativism (components of neuroticism) in competitive female athletes (Maliuchenko et al., 2007). These findings implicate genetic influences in neurotic behaviours in sport and such effects may be more or less prevalent when socially learned cues signal the appropriateness of such actions (a geneenvironment interaction effect). Research into the genetic and environmental influences on personality is a promising avenue of inquiry that can strengthen our understanding of both sport and exercise participation and athletic success. However, personality is important not only for the athlete but also for the people with whom they interact. This review now switches from person centred effects to consider the role of personality in between-person interactions in sport.

\section{Social interactions and group dynamics}

The contribution of personality to interpersonal relationships and group processes has received little attention in competitive sport. This is a little surprising since sport participation is governed by social interactions (Carron \& Eys, 2012) and personality has demonstrated an important role in interpersonal relationships and social behaviours in work, family and romantic encounters (Driskell, Goodwin, Salas, \& O’Shea, 2006; Leary \& Hoyle, 2009). There is compelling evidence outside the domain of competitive sport that personality traits are related to important interpersonal outcomes including relationship satisfaction, stability, conflict and commitment (Cuperman \& Ickes, 2009; Denissen, van Aken, \& Dubas, 2009; Malouff et al., 2010). In most instances these effects have been explored at the intrapersonal level - where self-report measures of personality are correlated with self-report 
measures of relationship variables (actor effects), but researchers have also observed important effects at the interpersonal level - where personality scores for one person are correlated with relationship variables of the other person (partner effects). By assessing both actor and partner effects it is possible to explore further how personality similarity (or dissimilarity) contributes to the maintenance and breakdown of interpersonal relationships in various social contexts (Cuperman \& Ickes, 2009).

The contribution of personality traits to successfully functioning interpersonal relationships has been noticeably absent from sport based research. However, two recent papers have made important advances towards redressing this balance. In a study of relationship commitment in (athlete-athlete) sporting dyads, Jackson and colleagues (Jackson, Dimmock, Gucciardi, \& Grove, 2010) observed that athletes were more committed to their athletic partnership when they rated themselves (or when their partner rated him/herself) as highly agreeable, conscientious, or open to new experiences. They also observed that athletes were more committed to their partnership when they rated their partner as highly agreeable, conscientious, and open to new experiences. Another study by Jackson and colleagues (Jackson, Dimmock, Gucciardi, \& Grove, 2011) explored how personality relates to relationship commitment and relatedness in coach-athlete dyads. They found that coaches and athletes were more committed and showed greater relatedness when they rated themselves as highly agreeable, conscientious, or extraverted, and reported increased perceptions of relatedness as well as commitment when their partner was highly agreeable and/or conscientious. The study also found that greater dissimilarity in personality traits (extraversion and openness) between athletes and coaches was associated with reduced commitment and perceptions of relatedness.

These findings compliment recent research in amateur coaches that found coaches perceive athletes as easier to instruct and mentor if they are highly agreeable and/or 
emotionally stable (Favor, 2011). The contribution of personality to relationship commitment and relatedness is apparent both inside and outside competitive sport (Jackson et al., 2011). However, the long-term effects of relatedness and commitment to relationship quality and longevity remain unknown. Research into these areas would be particularly valuable to practicing sport psychologists targeting interpersonal relationships in athleteathlete and coach-athlete dyads (see Jowett \& Nezlek, 2012; Rhind \& Jowett, 2011). However, personality is important not only for interpersonal relationships but also for behaviours related to group functioning and integration in sports teams. In one of the earliest reviews on the topic, Mann (1959) observed that components of personality are associated with how a person behaves and is perceived in small groups. This article was intended to serve as a platform for further research into personality and team effectiveness but it was not until recently that researchers began to uncover the personality characteristics that make an effective team player.

The contribution of personality to team performance has been explored in two recent systematic reviews. The first, a meta-analysis of ten independent samples and 527 teams, found that team performance was positively associated with average team levels of agreeableness $(\rho=.24)$ and conscientiousness $(\rho=.20)$, and that greater within-team variability in agreeableness $(\rho=-.12)$ and conscientiousness $(\rho=-.24)$ was negatively associated with team performance (Peeters et al., 2006a). The second, a meta-analysis of 22 - 39 independent samples and 1,439-2,243 teams, found that average team levels of agreeableness $(\rho=.12)$, conscientiousness $(\rho=.11)$ and extraversion $(\rho=.11)$ were positively associated with team performance (Bell, 2007). Moreover, when relationships were explored exclusively in field-based studies larger positive associations were found for agreeableness $(\rho=.31)$, conscientiousness $(\rho=.30)$, extraversion $(\rho=.15)$, and openness $(\rho=$ .20) dimensions. Although these systematic reviews did not include any samples from sport 
teams, the larger effect sizes in applied settings suggest that personality may have an important role in this context. It is interesting to note that these findings differ from metaanalyses of individual performance where agreeableness is unrelated to performance (Hurtz \& Donovan, 2000; Poropat, 2009). This suggests that the qualities that make an effective individual performer differ from those that make an effective team performer.

Both the average team personality and the variance in team members' personality appear to have important effects on global team performance. However, the relationship between individual differences in personality and team outcomes is contingent on the nature of the task (Driskell et al., 2006). Team performance is multidimensional and different personality characteristics are hypothesised to have different performance consequences (Driskell et al., 2006). Therefore, in order to understand these effects in more detail researchers have started to explore how personality relates to components of group dynamics associated with team performance. In particular, researchers (in non-athletic domains) have explored the contribution of team member personality to components of team cohesion and team satisfaction. In addition to analysing average team personality and variances, studies have also analysed how extreme scores (minimum and maximum) contribute to hypothesised relationships. This allows researchers to identify whether a particular team member (someone dissimilar to other members of the group) is having a destructive influence (or a constructive influence) on team outcomes.

In two large sample studies of established organisational teams, higher levels of social cohesion were predicted by higher mean levels of extraversion and emotional stability (Barrick, Stewart, Neubert, \& Mount, 1998; Van Vianen \& De Dreu, 2001). Further, using the minimum scores method these studies observed that higher minimum levels of extraversion and emotional stability were associated with higher levels of social cohesion. These findings demonstrate that a single introverted or emotionally unstable individual can 
affect the extent to which the group as a whole is socially cohesive. In addition to personality effects on social cohesion, Van Vianen and De Dreu (2001) also found that higher minimum levels of conscientiousness and agreeableness were associated with higher average levels of task cohesion. This suggests that a single disagreeable or apathetic individual can disrupt a team's task-directed unity.

Alongside personality effects on team cohesion, researchers have also explored personality effects on team satisfaction. In a study of student work groups, greater satisfaction with the team was associated with higher mean levels of agreeableness and emotional stability, and greater similarity in conscientiousness (Peeters, Rutte, Van Tuijl, \& Reymen, 2006b). This study also found that greater dissimilarity in extraversion was associated with lower levels of satisfaction but only for those team members with low levels of extraversion (a mean-variance interaction effect). In another study of student work groups, greater personal dissimilarity in conscientiousness (dissimilarity from other group members) was shown to have a negative effect on team members' satisfaction with the team, and team dissimilarity in conscientiousness (team variance) was shown to have a negative effect on both satisfaction with the team and satisfaction with the team's performances (Gevers \& Peeters, 2009). These studies not only demonstrate important relationships in student work groups but also highlight the different approaches that can be used to explore associations in group-based personality research. The choice of whether to explore group means, group variances, personal variances, minimum and maximum scores, or mean-variance interactions will depend largely on the research question being asked and we encourage researchers to consider these designs in personality-based research in team sport.

There are good reasons to expect personality to predict success in sports teams based on the theoretical predictions that govern associations between personality and team effectiveness in small groups (Driskell et al., 2006; LePine, Buckman, Crawford, \& Methot, 
2011). However, the relationship between personality and team performance is contingent on the nature of the task (Driskell et al., 2006) and a number of moderating variables including team experience, team confidence, team stability, and levels of interdependence can affect the magnitude of associations between personality dimensions and team success (Bell, 2007; O’Neill \& Allen, 2011; Tasa, Sears, \& Schat, 2011). These relationships require urgent empirical attention in team sport given the practical advantages of being able to statistically predict team success on the bases of team members' personality. We now consider in a little more detail the practical relevance of personality research to sport psychology consultants.

\section{Practical application of personality research}

There is considerable practical as well as theoretical value in being able to statistically predict athletic behaviour. In addition to being able to select (or deselect) appropriate persons to fit the needs of a team (or a particular competition) understanding personality can help coaches and practitioners identify athletes requiring greater support during important personal or career transitions (see Laurin, 2009). Because personality is consistent and enduring (Pervin \& Cervone, 2010), it would not be practical to design interventions that target the suppression or expression of various personality characteristics. However, team members and coaching staff can be trained to facilitate integration of persons for whom social interaction and integration can be difficult (Beauchamp, Jackson, \& Lavallee, 2007). Moreover, personality assessments become crucial when personality is shown to moderate causal relationships essential to athletic success. If personality can affect how athletes respond to positive and negative emotions (Woodman et al., 2009) this information has important consequences for the emotional control strategies targeted towards certain groups of athletes.

In addition to changing how practitioners might approach other intervention topics, personality assessments can also be used to create awareness of personality effects. To 
explain, personality has an important role in interpersonal relationships in sport (Jackson et al., 2011) and personality assessments could be used to identify athletes and coaches more susceptible to clashes and disputes. By creating awareness that coaches and athletes are susceptible to such personality clashes it becomes possible to develop intervention strategies that support relationships if and when these conflicts arise. A greater awareness of personality effects in team settings can also help individuals to communicate and interact more effectively with their teammates and prevent members adopting tendencies that might conflict with those of other team members (Beauchamp et al., 2007).

The relevance of personality also extends beyond the content of interventions to the manner in which those interventions are delivered. That is, sport psychology consultants need to be aware of their own personality and how it can affect their relationships with clients including the engagement in and acceptance of recommended intervention strategies. Indeed, many practitioners would agree that the first consultation with a new client is as much about developing a rapport (contingent on understanding the clients' personality) as it is about developing an understanding of their personal and sporting background. It is likely that sport psychologists intuitively adjust their consultancy style to satisfy the needs of their clients and this is contingent on developing an understanding of the client's personality. In fact, it is difficult to envision a consultation that is not in some way tailored towards the individual needs of the client. Unfortunately, personality effects on client-practitioner relationships have not featured in sport-based research. This information would be particularly valuable to those working in both amateur and professional sport settings and is an important avenue for future sport personality research.

These are just a few of the practical advantages that can be gained by undertaking a programme of research into personality in sport and we expect that readers can fathom many others to supplement these. How research moves forward from here depends largely on the 
interests and aspirations of researchers, and the topics we have run through represent our own outlook on the areas we feel would best suit the progression of this field. We conclude this review by summarising what we know (and what we do not know) and briefly describing an assortment of research questions we feel offer the best prospects for moving sport-based personality research forward.

\section{Summary and future research directions}

Over the last few years (since the turn of the 2010s) personality research has started to re-emerge as an important academic pursuit following a near 20 year hiatus from organised sport. Our motivation in writing this review was not only to synthesise the current state of knowledge in this important field, but also to address gaps in our knowledge and illustrate the applied relevance of personality research to practicing sport psychologists. Through our discussions it may appear as though there are more gaps in the literature than actual substance. However, our reading has led us to a number of conclusions about the role of personality in competitive sport. First, there is good evidence from population comparison and longitudinal research that long-term success and short-term behaviours can be predicted by personality traits (although the importance of each personality dimension remain unknown). There is also good evidence that personality test scores can discriminate between athletes and non-athletes, and between different populations of athletes. In particular, athletes consistently show higher levels of extraversion than non-athletes, and team sport athletes (and high risk sport athletes) show higher levels of extraversion and lower levels of conscientiousness than individual sport athletes (and low risk sport athletes).

That these are the most noteworthy findings after nearly 70 years of research is a little disappointing. Indeed, we still have almost no information about the size of these effects and these will become clearer once a more substantial body of research has accumulated and researchers are able to quantitatively synthesise study findings. In the meantime, researchers 
would do well to report population based differences as auxiliary findings whenever publishing empirical studies on personality in sport. Furthermore, with most studies being published prior to the development of the five factor model, the contribution of agreeableness, openness, and conscientiousness are less compelling than those of extraversion and neuroticism. The value of the five factor model is that it encompasses most of the variance in trait personality descriptions and brings order to an otherwise chaotic description of personality measures in a simple set of hierarchically structured dimensions (Funder, 2001). We encourage researchers to adopt this framework in future studies of personality in sport.

Alongside performance consequences and population based differences, researchers may also wish to explore how the five personality dimensions contribute to athletic behaviours during the lead up to competition (e.g. self-handicapping, cardiovascular responses to stress), critical events during competition (e.g. attention processes, coping strategies, leadership behaviour), athlete responses to competition (e.g. attributions, counterfactual thinking), and important issues outside of competition (e.g. burnout, eating disorders). Researchers should also focus on the processes underlying observed relationships between personality traits and outcomes (see Hampson, 2012) and move beyond the conventional focus on the individual athlete to consider a wider focus on the role of personality in social interactions and group processes. One area of research that we particularly encourage is personality continuity and sport participation. Longitudinal developmental studies can help to shed light on whether the interaction of genetic and environmental (e.g. family) influences contribute to sport participation and whether sport participation (in combination with genetic influences) can facilitate maturational (personality) development. 
Validation efforts are also required for personality assessments commonly used in athletic samples. The recently revised NEO-PI-3 and NEO-FFI-3 scales (Costa \& McCrae, 2010), derived from the NEO-PI-R and the NEO-FFI (Costa \& McCrae, 1992), have shown evidence of construct and concurrent validity in non-athletic samples (McCrae \& Costa, 2007), as have the big five inventory (John et al., 2008), the international personality item pool (Goldberg et al., 2006), and the ten item personality inventory (Gosling, Rentfrow, \& Swann, 2003). These measures can be used in both self-report and other-report formats and there is an urgent need to assess the validity and reliability of these instruments in adult and youth sport populations. The scales can then be used to identify how the five dimensions of personality relate to various personal, interpersonal, and social behaviours in individual and team sport competitions.

In this review we have attempted to lay the groundwork for a new era of personality research, rather than simply provide a structured dissection of the available literature. Many of the topics covered here have so far attracted no interest from sport psychology researchers and this may reflect the (rather undeserved) scepticism surrounding the predictive utility of personality in sport. But while sport personality research has stagnated, personality research in general has continued to prosper and we now have well supported conceptual models (e.g. McCrae \& Costa, 2008) and an abundance of validated measurement tools (see John et al., 2008) to support the progression of this field. We hope readers have found this review insightful and (for some) have been inspired to undertake a programme of research into personality in sport. 


\section{References}

Aidman, E. V. (2007). Attribute-based selection for success: The role of personality attributes in long-term predictions of achievement in sport. The Journal of the American Board of Sport Psychology, 3, 1-18.

Alarcon, G., Eschleman, K. J., \& Bowling, N. A. (2009). Relationship between personality variables and burnout: A meta-analysis. Work \& Stress, 23(3), 244-263.

Allen, M. S., Frings, D., \& Hunter, S. (2012). Personality, coping, and challenge and threat states in athletes. International Journal of Sport and Exercise Psychology.

Allen, M. S., Greenlees, I., \& Jones, M. V. (2011). An investigation of the five-factor model of personality and coping behaviour in sport. Journal of Sports Sciences, 29(8), 841850.

Allport, G. W. (1927). Concepts of trait and personality. Psychological Bulletin, 24(5), 284293.

Allport, G. W. (1937). Personality: A psychological interpretation. New York, NY: Holt.

Arias, B., Aguilera, M., Moya, J., Sáiz, P. A., Villa, H., Ibáñez, M. I., ... Fananás, L. (2012). The role of genetic variability in the SLC6A4, BDNF and GABRA6 genes in anxietyrelated traits. Acta Psychiatrica Scandinavica, 125, 194-202.

Asendorpf, J. B. (2003). Head-to-head comparison of the predictive validity of personality types and dimensions. European Journal of Personality, 17, 327-346.

Baker, J. (2007). Nature and nurture interact to create expert performers. High Ability Studies, 18(1), 57-58.

Barenbaum, N. B., \& Winter, D. G. (2008). History of modern personality theory and research. In O. P. John, R. W. Robins, \& L. A. Pervin (Eds.), Handbook of personality: Theory and research ( $3^{\text {rd }}$ ed., pp. 3-26). New York, NY: Guilford Press. 
Barrick, M. R., \& Mount, M. K. (1991). The big five personality dimensions and job performance: A meta-analysis. Personnel Psychology, 44, 1-26.

Barrick, M. R., Stewart, G. L., Neubert, M. J., \& Mount, M. K. (1998). Relating member ability and personality to work-team processes and team effectiveness. Journal of Applied Psychology, 83(3), 377-391.

Beauchamp, M. R., Jackson, B., \& Lavallee, D. (2007). Personality processes and intra-group dynamics in sport teams. In M. R. Beauchamp \& M. A. Eys (Eds.), Group dynamics in exercise and sport psychology: Contemporary themes (pp. 25-41). Oxon, UK: Routledge.

Bell, S. T. (2007). Deep-level composition variables as predictors of team performance: A meta-analysis. Journal of Applied Psychology, 92(3), 595-615.

Biddle, S. J. H., Atkin, A. J., Cavill, N., \& Foster, C. (2011). Correlates of physical activity in youth: A review of quantitative systematic reviews. International Review of Sport and Exercise Psychology, 4(1), 25-49.

Block, J. (2010). The five-factor framing of personality and beyond: Some ruminations. Psychological Inquiry, 21, 2-25.

Bono, J. E., \& Judge, T. A. (2004). Personality and transformational leadership: A metaanalysis. Journal of Applied Psychology, 89(5), 901-910.

Booth, E. G. (1958). Personality traits of athletes as measured by the MMPI. Research Quarterly, 29(2), 127-138.

Cameron, J. E., Cameron, J. M., Dithurbide, L., \& Lalonde, R. N. (2012). Personality traits and stereotypes associated with ice hockey positions. Journal of Sport Behavior, 35, 109-124.

Carron, A. V., \& Eys, M. A. (2012). Group dynamics in sport (4 ${ }^{\text {th }}$ ed.). Morgantown, WV: Fitness Information Technology. 
Carter, G. C., \& Shannon, J. R. (1940). Adjustment and personality traits of athletes and nonathletes. School Review, 48, 127-130.

Carver, C. S., \& Connor-Smith, J. (2010). Personality and coping. Annual Review of Psychology, 61, 679-704.

Caspi, A., McClay, J., Moffitt, T. E., Mill, J., Martin, J., Craig, I. W., ... Poulton, R. (2002). Role of genotype in the cycle of violence in maltreated children. Science, 297(5582), $851-854$.

Caspi, A., Roberts, B. W., \& Shiner, R. L. (2005). Personality development: Stability and change. Annual Review of Psychology, 79, 644-655.

Castanier, C., Le Scanff, C., \& Woodman, T. (2010). Who takes risks in high-risk sports? A typological personality approach. Research Quarterly for Exercise and Sport, 81(4), 478-485.

Clarke, H., Flint, J., Attwood, A. S., \& Munafò, M. R. (2010). Association of the 5-HTTLPR genotype and unipolar depression: A meta-analysis. Psychological Medicine, 40(11), 1767-1778.

Coetzee, N. (2010). Personality profiles of recreational scuba divers. African Journal for Physical, Health Education, Recreation and Dance, 16(4), 568-579.

Colley, A., Roberts, N., \& Chipps, A. (1985). Sex-role identity, personality and participation in team and individual sports by males and females. International Journal of Sport Psychology, 16(2), 103-112.

Connor-Smith, J. K., \& Flachsbart, C. (2007). Relations between personality and coping: A meta-analysis. Journal of Personality and Social Psychology, 93, 1080-1107.

Costa, P. T., \& McCrae, R. R. (1992). Revised NEO personality inventory and NEO fivefactor inventory: Professional manual. Odessa, FL: Psychological Assessment Resources. 
Costa, P. T., \& McCrae, R. R. (2010). NEO inventories: Professional manual. Odessa, FL: Psychological Assessment Resources.

Costa, P. T., Terracciano, A., \& McCrae, R. R. (2001). Gender differences in personality traits across cultures: Robust and surprising findings. Journal of Personality and Social Psychology, 81, 322-331.

Cox, R. H., \& Yoo, H. S. (1995). Playing position and psychological skill in American football. Journal of Sport Behavior, 18(3), 183-194.

Cuperman, R., \& Ickes, W. (2009). Big five predictors of behavior and perceptions in initial dyadic interactions: Personality similarity helps extraverts and introverts, but hurts “disagreeables”. Journal of Personality and Social Psychology, 97(4), 667-684.

Davids, K., \& Baker, J. (2007). Genes, environment and sport performance: Why the naturenurture dualism is no longer relevant. Sports Medicine, 37(11), 961-980.

Davis, C., \& Mogk, J. P. (1994). Some personality correlates of interest and excellence in sport. International Journal of Sport Psychology, 25(2), 131-143.

De Geus, E. J. C., \& De Moor, M. H. M. (2011). Genes, exercise, and psychological factors. In C. Bouchard \& E. P. Hoffman (Eds.), Genetic and molecular aspects of sport performance (pp. 294-305). Oxford, UK: Wiley-Blackwell.

De Moor, M. H. M., Costa, P. T., Terracciano, A., Krueger, R. F., De Geus, E. J. C., Toshiko, T. ... Boomsma, D. I. (2012). Meta-analysis of genome-wide association studies for personality. Molecular Psychiatry, 17, 337-349.

Denissen, J. J. A., van Aken, M. A. G., \& Dubas, J. S. (2009). It takes two to tango: How parents' and adolescents' personalities link to the quality of their mutual relationship. Developmental Psychology, 45(4), 928-941.

Digman, J. M. (1989). Five robust trait dimensions: Development, stability, and utility. Journal of Personality, 57, 195-214. 
Dowd, R., \& Innes, J. M. (1981). Sport and personality: Effects of type of sport and level of competition. Perceptual and Motor Skills, 53(1), 79-89.

Driskell, J. E., Goodwin, G. F., Salas, E., \& O’Shea, P. G. (2006). What makes a good team player? Personality and team effectiveness. Group Dynamics: Theory, Research, and Practice, 10(4), 249-271.

Eagleton, J. R., McKelvie, S. J., \& De Man, A. (2007). Extraversion and neuroticism in team sport participants, individual sport participants, and non-participants. Perceptual and Motor Skills, 105, 265-275.

Egan, S., \& Stelmack, R. M. (2003). A personality profile of Mount Everest climbers. Personality and Individual Differences, 34, 1491-1494.

Egloff, B., \& Jan Gruhn, A. (1996). Personality and endurance sports. Personality and Individual Differences, 21, 223-229.

Evans, V., \& Quarterman, J. (1983). Personality characteristics of successful and unsuccessful black female basketball players. International Journal of Sport Psychology, 14, 105-115.

Fauqier, W. (1940). The attitudes of aggressive and submissive boys toward athletics. Child Development, 11, 115-125.

Favor, J. K. (2011). The relationship between personality traits and coachability in NCAA Division I and II female softball players. International Journal of Sports Science \& Coaching, 6(2), 301-314.

Feingold, A. (1994). Gender differences in personality: A meta-analysis. Psychological Bulletin, 116, 429-456.

Fisher, A. C. (1984). New directions in sport personality research. In J. M. Silva \& R. S. Weinberg (Eds.), Psychological foundations of sport (pp. 70-80). Champaign, IL: Human Kinetics. 
Flanagan, L. (1951). A study of some personality traits of different physical activity groups. Research Quarterly, 22(3), 312-323.

Fleming, E. G. (1934). Personality and the athletic girl. School and Society, 39, 166-169.

Frazier, S. E. (1987). Introversion-extraversion measure in elite and non-elite distance runners. Perceptual and Motor Skills, 64, 867-872.

Funder, D. C. (2001). Personality. Annual Review of Psychology, 52, 197-221.

Funder, D. C., \& Fast, L. A. (2010). Personality in social psychology. In D. Gilbert \& S. Fiske (Eds.), Handbook of social psychology (5 ${ }^{\text {th }}$ ed., pp. 668-697). New York, NY: Wiley.

Garland, D. J., \& Barry, J. R. (1990). Personality and leader behaviors in collegiate football: A multidimensional approach to performance. Journal of Research in Personality, 24(3), 355-370.

Gat, I., \& McWhirter, B. T. (1998). Personality characteristics of competitive and recreational cyclists. Journal of Sport Behavior, 21(4), 408-420.

Gee, C. J., Marshall, J. C., \& King, J. F. (2010). Should coaches use personality assessments in the talent identification process? A 15 year predictive study on professional hockey players. International Journal of Coaching Science, 4, 25-34.

Geron, E., Furst, D., \& Rotstein, P. (1986). Personality of athletes participating in various sports. International Journal of Sport Psychology, 17(2), 120-135.

Gevers, J. M. P., \& Peeters, M. A. G. (2009). A pleasure working together? The effects of dissimilarity in team member conscientiousness on team temporal processes and individual satisfaction. Journal of Organizational Behavior, 30, 379-400.

Gill, D. L., \& Williams, L. (2008). Psychological dynamics of sport and exercise ( $3^{\text {rd }}$ ed.). Champaign, IL: Human Kinetics. 
Golby, J., \& Sheard, M. (2006). The relationship between genotype and positive psychological development in national-level swimmers. European Psychologist, $11(2), 143-148$.

Goldberg, L. R., Johnson, J. A., Eber, H. W., Hogan, R., Ashton, M. C., Cloninger, C. R., \& Gough, H. G. (2006). The international personality item pool and the future of publicdomain personality measures. Journal of Research in Personality, 40, 84-96.

Gosling, S. D., Rentfrow, P. J., \& Swann, W. B. (2003). A very brief measure of the big-five personality domains. Journal of Research in Personality, 37, 504-528.

Graydon, J., \& Murphy, T. (1995). The effects of personality on social facilitation whilst performing a sports related task. Personality and Individual Differences, 19(2), 265267.

Greenwood, M., \& Simpson, W. K. (1994). Personality traits of intercollegiate baseball athletes playing central versus noncentral defensive positions at three levels of competition. Applied Research in Coaching \& Athletics Annual, 1, 15-30.

Griffith, C. R. (1926). The psychology of coaching: A study of coaching methods from the point of psychology. New York, NY: Scribners.

Griffith, C. R. (1930). A laboratory for research in athletics. Research Quarterly, 1, 34-40.

Gucciardi, D., \& Gordon, S. (2011). Mental toughness in sport: Developments in theory and research. East Sussex, UK: Routledge.

Hampson, S. E. (2012). Personality processes: Mechanisms by which personality traits "get outside the skin". Annual Review of Psychology, 63, 315-339.

Hankin, B. L., Jenness, J., Abela, J. R. Z., \& Smolen, A. (2011). Interaction of 5-HTTLPR and idiographic stressors predicts prospective depressive symptoms specifically among youth in a multiwave design. Journal of Clinical Child \& Adolescent Psychology, 40(4), 572-585. 
Hershberger, S. L., Plomin, R., \& Pedersen, N. L. (1995). Traits and meta-traits: Their reliability, stability, and shared genetic influence. Journal of Personality and Social Psychology, 69, 673-685.

Horn, T. S. (2008). Advances in sport psychology ( $3^{\text {rd }}$ ed.). Champaign, IL: Human Kinetics.

Hughes, S. L., Case, H. S., Stumempfle, K. J., \& Evans, D. S. (2003). Personality profiles of Iditasport ultra-marathon participants. Journal of Applied Sport Psychology, 15, 256261.

Hurtz, G. M., \& Donovan, J. J. (2000). Personality and job performance: The big five revisited. Journal of Applied Psychology, 85(6), 869-879.

Jackson, B., Dimmock, J. A., Gucciardi, D. F., \& Grove, J. R. (2010). Relationship commitment in athletic dyads: Actor and partner effects for big five self- and otherratings. Journal of Research in Personality, 44, 641-648.

Jackson, B., Dimmock, J. A., Gucciardi, D. F., \& Grove, J. R. (2011). Personality traits and relationship perceptions in coach-athlete dyads: Do opposites really attract? Psychology of Sport and Exercise, 12, 222-230.

John, O. P. (1990). The "Big Five" factor taxonomy: Dimensions of personality in the natural language and questionnaires. In L. A. Pervin (Ed.), Handbook of personality: Theory and research (pp. 66-100). New York, NY: Guilford Press.

John, O. P., Naumann, L. P., \& Soto, C. J. (2008). Paradigm shift to the integrative big five trait taxonomy: History, measurement, and conceptual issues. In O. P. John, R. W. Robins, \& L. A. Pervin (Eds.), Handbook of personality: Theory and research $\left(^{\text {rd }}\right.$ ed., pp. 114-158). New York, NY: Guilford Press.

Johnson, R. W., \& Morgan, W. P. (1981). Personality characteristics of college athletes in different sports. Scandinavian Journal of Sports Science, 3, 41-49. 
Jowett, S., \& Nezlek, J. (2012). Relationship interdependence and satisfaction with important outcomes in coach-athlete dyads. Journal of Social and Personal Relationships, 29, 287-301.

Judge, T. A., Bono, J. E., Ilies, R., \& Gerhardt, M. W. (2002). Personality and leadership: A qualitative and quantitative review. Journal of Applied Psychology, 87(4), 765-780.

Judge, T. A., Heller, D., \& Mount, M. K. (2002). Five-factor model of personality and job satisfaction: A meta-analysis. Journal of Applied Psychology, 87, 530-541.

Judge, T. A., \& Ilies, R. (2002). Relationship of personality to performance motivation: A meta-analytic review. Journal of Applied Psychology, 87(4), 797-807.

Kaiseler, M., Polman, R. C. J., \& Nicholls, A. R. (2012). Effects of the big five personality dimensions on appraisal coping, and coping effectiveness in sport. European Journal of Sport Science, 12, 62-72.

Kajtna, T., Tušak, M., Barić, R., \& Burnik, S. (2004). Personality in high-risk sport athletes. Kinesiology, 36, 24-34.

Kirkaldy, B. D. (1982a). Personality profiles at various levels of athletic participation. Personality and Individual Differences, 3, 321-326.

Kirkaldy, B. D. (1982b). Personality and sex differences related to positions in team sports. International Journal of Sport Psychology, 13, 141-153.

Knab, A. M., \& Lightfoot, J. T. (2010). Does the difference between being physically active and couch potato lie in the dopamine system? International Journal of Biological Sciences, 6(2), 133-150.

Krueger, R. F., \& Johnson, W. (2008). Behavioral genetics and personality: A new look at the integration of nature and nurture. In O. P. John, R. W. Robins, \& L. A. Pervin (Eds.), Handbook of personality: Theory and research ( $3^{\text {rd }}$ ed., pp. 287-310). New York, NY: Guilford Press. 
Krueger, R. F., South, S., Johnson, W., \& Iacono, W. (2008). The heritability of personality is not always 50\%: Gene-environment interactions and correlations between personality and parenting. Journal of Personality, 76(6), 1485-1521.

La Place, J. P. (1954). Personality and its relationship to success in professional baseball. Research Quarterly, 25(3), 313-319.

Lackie, W. L. (1962). Personality characteristics of certain groups of intercollegiate athletes. Research Quarterly, 33, 566-573.

Laurin, R. (2009). The influence of the "big five" factors on the demands-abilities fit in soccer academies. Perceptual and Motor Skills, 109, 239-250.

Leary, M. R., \& Hoyle, R. H. (2009). Handbook of individual differences in social behavior. New York, NY: Guilford.

LePine, J. A., Buckman, B. R., Crawford, E. R., \& Methot, J. R. (2011). A review of research on personality in teams: Accounting for pathways spanning levels of theory and analysis. Human Resource Management Review, 21, 311-330.

Lightfoot, J. T. (2011). Current understanding of the genetic basis for physical activity. Journal of Nutrition, 141, 512-514.

Lippi, G., Longo, U. G., \& Maffulli, N. (2010). Genetics and sports. British Medical Bulletin, $93,27-47$.

Loehlin, J. C., Willerman, L., \& Horn, J. M. (1985). Personality resemblances in adoptive families when the children are late-adolescent or adult. Journal of Personality and Social Psychology, 48, 376-392.

Maliuchenko, N. V., Sysoeva, O. V., Vediakov, A. M., Timofeeva, M. A., Portanova, G. V., Ivanitski, A. M., ... Kirpichnikov, M. P. (2007). Effect of 5HTT genetic polymorphism on aggression in athletes. Zhurnal Vysshei Nervnoi Deiatelnosti Imeni I P Pavlova, 57(3), 276-281. 
Malouff, J. M., Thorsteinsson, E. B., Rooke, S. E., \& Schutte, N. S. (2007). Alcohol involvement and the five-factor model of personality: A meta-analysis. Journal of Drug Education, 37(3), 277-294.

Malouff, J. M., Thorsteinsson, E. B., \& Schutte, N. S. (2006). The five-factor model of personality and smoking: A meta-analysis. Journal of Drug Education, 36(1), 47-58.

Malouff, J. M., Thorsteinsson, E. B., Schutte, N. S., Bhullar, N., \& Rooke, S. E. (2010). The five-factor model of personality and relationship satisfaction of intimate partners: A meta-analysis. Journal of Research in Personality, 44(1), 124-127.

Mann, R. D. (1959). A review of the relationships between personality and performance in small groups. Psychological Bulletin, 56, 241-270.

Martin, J. J., Malone, L. A., \& Hilyer, J. C. (2011). Personality and mood in women's Paralympic basketball champions. Journal of Clinical Sport Psychology, 5(3), $197-$ 210.

McAdams, D. P., \& Olson, B. D. (2010). Personality development: Continuity and change over the life course. Annual Review of Psychology, 61, 517-542.

McCrae, R. R., \& Costa, P. T. (1987). Validation of the five-factor model of personality across instruments and observers. Journal of Personality and Social Psychology, 52, $81-90$.

McCrae, R. R., \& Costa, P. T. (1989). Reinterpreting the Myers-Briggs Type Indicator from the perspective of the five-factor model of personality. Journal of Personality, 57, 1740.

McCrae, R. R., \& Costa, P. T. (2007). Brief versions of the NEO-PI-3. Journal of Individual Differences, 28, 116-128. 
McCrae, R. R., \& Costa, P. T. (2008). The five-factor theory of personality. In O. P. John, R. W. Robins, \& L. A. Pervin (Eds.), Handbook of personality: Theory and research $\left(3^{\text {rd }}\right.$ ed., pp. 159-181). New York, NY: Guilford Press.

McCrae, R. R., \& John, O. P. (1992). An introduction to the five-factor model and its applications. Journal of Personality, 60, 175-215.

McKelvie, S. J., Lemieux, P., \& Stout, D. (2003). Extraversion and neuroticism in contact athletes, no contact athletes and non-athletes: A research note. Athletic Insight, 5(3), $19-27$.

Merriman, J. B. (1960). Relationship of personality traits to motor ability. Research Quarterly, 31(2), 163-173.

Michel, J. S., Clark, M. A., \& Jaramillo, D. (2011). The role of the five factor model of personality in the perceptions of negative and positive forms of work-nonwork spillover: A meta-analytic review. Journal of Vocational Behavior, 79(1), 191-203.

Morgan, W. P. (1968). Personality characteristics of wrestlers participating in the world championships. Journal of Sports Medicine and Physical Fitness, 8, 212-216.

Morgan, W. P., \& Johnson, R. W. (1978). Personality characteristics of successful and unsuccessful oarsmen. International Journal of Sport Psychology, 9, 119-133.

Munafò, M. R., Clark, T. G., Moore, L. R., Payne, E., Walton, R., \& Flint, J. (2003). Genetic polymorphisms and personality in healthy adults: A systematic review and metaanalysis. Molecular Psychiatry, 8, 471-484.

Munafò, M. R., Freimer, N. B., Ng, W., Ophoff, R., Veijola, J., Miettunen, J., ... Flint, J. (2009). 5-HTTLPR genotype and anxiety-related personality traits: A meta-analysis and new data. American Journal of Medical Genetics B - Neuropsychiatric Genetics, $150 B(2), 271-281$. 
Munafò, M. R., Yalcin, B., Willis-Owen, S. A., \& Flint, J. (2008). Association of the dopamine D4 receptor (DRD4) gene and approach-related personality traits: Metaanalysis and new data. Biological Psychiatry, 63, 197-206.

Newcombe, P. A., \& Boyle, G. (1995). High school students' sports personalities: Variations across participation level, gender, type of sport, and success. International Journal of Sport Psychology, 26, 277-294.

Nia, M. E., \& Besharat, M. A. (2010). Comparison of athletes' personality characteristics in individual and team sports. Procedia Social and Behavioral Sciences, 5, 808-812.

Noble, E. P., Ozkaragoz, T. Z., Ritchie, T. L., Zhang, X., Belin, T. R., \& Sparkes, R. S. (1998). $\mathrm{D}_{2}$ and $\mathrm{D}_{4}$ dopamine receptor polymorphisms and personality. American Journal of Medical Genetics, 81, 257-267.

O’Neill, T. A., \& Allen, N. J. (2011). Personality and the prediction of team performance. European Journal of Personality, 25, 31-42.

O’Rourke, D. J., Smith, R. E., Smoll, F. L., \& Cumming, S. P. (2011). Trait anxiety in young athletes as a function of parental pressure and motivational climate: Is parental pressure always harmful? Journal of Applied Sport Psychology, 23(4), 398-412.

O’Sullivan, D. M., Zuckerman, M., \& Kraft, M. (1998). Personality characteristics of male and female participants in team sports. Personality and Individual Differences, 25(1), 119-128.

Oh, I-S., Wang, G., \& Mount, M. K. (2011). Validity of observer ratings of the five-factor model of personality traits: A meta-analysis. Journal of Applied Psychology, 96(4), $762-773$.

Ozer, D. J., \& Benet-Martínez, V. (2006). Personality and the prediction of consequential outcomes. Annual Review of Psychology, 57, 401-421. 
Paunonen, S. V. (2003). Big five factors of personality and replicated predictors of behavior. Journal of Personality and Social Psychology, 84(2), 411-424.

Pedersen, N. L., Plomin, R., McClearn, G. E., \& Friberg, L. (1988). Neuroticism, extraversion, and related traits in adult twins reared apart and reared together. Journal of Personality and Social Psychology, 55, 950-957.

Peeters, M. A. G., Van Tuijl, H. F. J. M., Rutte, C. G., \& Reymen, I. M. M. J. (2006a). Personality and team performance: A meta-analysis. European Journal of Personality, 20, 377-396.

Peeters, M. A. G., Rutte, C. G., Van Tuijl, H. F. J. M., \& Reymen, I. M. M. J. (2006b). The big five traits and individual satisfaction with the team. Small Group Research, 37(2), 187-211.

Pervin, L. A., \& Cervone, D. (2010). Personality: Theory and research (11 ${ }^{\text {th }}$ ed.). New York, NY: Wiley.

Peterson, S. L., Weber, J. C., \& Trousdale, W. W. (1967). Personality traits of women in team sports vs. women in individual sports. Research Quarterly, 38, 686-690.

Piedmont, R. L., Hill, D. C., \& Blanco, S. (1999). Predicting athletic performance using the five-factor model of personality. Personality and Individual Differences, 27, 769-777.

Pittenger, D. J. (2004). The limitations of extracting typologies from trait measures of personality. Personality and Individual Differences, 37, 779-787.

Poropat, A. E. (2009). A meta-analysis of the five-factor model of personality and academic performance. Psychological Bulletin, 135, 322-338.

Poropat, A. E. (2011). The Eysenckian personality factors and their correlations with academic performance. British Journal of Educational Psychology, 81(1), 41-58. 
Rhea, D. J., \& Martin, S. (2010). Personality trait differences of traditional sport athletes, bullriders, and other alternative sport athletes. International Journal of Sports Science and Coaching, 5(1), 75-85.

Rhind, D. J. A., \& Jowett, S. (2011). Working with coach-athlete relationships: Their quality and maintenance. In S. Mellalieu, \& S. Hanton (eds.), Professional practice in sport psychology: A review (pp. 219-248). London, UK: Routledge.

Rhodes, R. E., \& Pfaeffli, L. A. (2012). Personality. In E. O. Acevedo (Ed.), The Oxford handbook of exercise psychology. New York, NY: Oxford University Press.

Rhodes, R. E., \& Smith, N. E. (2006). Personality correlates of physical activity: A review and meta-analysis. British Journal of Sports Medicine, 40(12), 958-965.

Riemann, R., Angleitner, A., \& Strelau, J. (1997). Genetic and environmental influences on personality: A study of twins reared together using the self- and peer report NEO-FFI scales. Journal of Personality, 65, 449-475.

Roberts, B. W., \& DelVecchio, W. F. (2000). The rank-order consistency of personality traits from childhood to old age. Psychological Bulletin, 126, 3-25.

Roberts, B. W., Walton, K. E., \& Viechtbauer, W. (2006). Patterns of mean-level change in personality traits across the life course: A meta-analysis of longitudinal studies. Psychological Bulletin, 132, 1-25.

Rogulj, N., Nazor, M., Srhoj, V., \& Božin, D. (2006). Differences between competitively efficient and less efficient junior handball players according to their personality traits. Kinesiology, 38(2), 158-163.

Schinka, J. A., Busch, R. M., \& Robichaux-Keene, N. (2004). A meta-analysis of the association between the serotonin transporter gene polymorphism (5-HTTLPR) and trait anxiety. Molecular Psychiatry, 9(2), 197-202. 
Schinka, J. A., Letsch, E. A., \& Crawford, F. C. (2002). DRD4 and novelty seeking: Results of meta-analyses. American Journal of Medical Genetics, 114(6), 643-648.

Schmitt, D. P., Realo, A., Voracek, M., \& Allik, J. (2008). Why can't a man be more like a woman? Sex differences in big five personality traits across 55 cultures. Journal of Personality and Social Psychology, 94(1), 168-182.

Schurr, K. T., Ashley, M. A., \& Joy, K. J. (1977). A multivariate analysis of male athlete personality characteristics: Sport type and success. Multivariate Experimental Clinical Research, 3(2), 53-68.

Schurr, K. T., Ruble, V. E., Nisbet, J., \& Wallace, D. (1984). Myers-Briggs Type Inventory characteristics of more and less successful players on an American football team. Journal of Sport Behavior, 7(2), 47-57.

Scollon, C. N., \& Diener, E. (2006). Love, work, and changes in extraversion and neuroticism over time. Journal of Personality and Social Psychology, 91, 1152-1165.

Sindik, J. (2010). Relationship between big five personality markers with situation-related performance at top Croatian basketball players. Sport Science, 3, 34-38.

Sperling, A. P. (1942). Relationship between personality adjustment and achievement in physical education activities. Research Quarterly, 13, 351-363.

Stubbe, J. H., Boomsma, D. I., \& De Geus, E. J. C. (2005). Sports participation during adolescence: A shift from environmental to genetic factors. Medicine and Science in Sports and Exercise, 37, 563-570.

Stubbe, J. H., Boomsma, D. I., Vink, J. M., Cornes, B. K., Martin, N. G., Skytthe, A., ... De Geus, E. J. C. (2006). Genetic influences on exercise participation in 37.051 twin pairs from seven countries. PLoS ONE, 1(1), e22.

Stubbe, J. H., \& De Geus, E. J. C. (2009). Genetics of exercise behavior. In Y.-K. Kim (Ed.), Handbook of Behavior Genetics (pp. 343-358). Berlin: Springer. 
Tasa, K., Sears, G. J., \& Schat, A. C. H. (2011). Personality and teamwork behavior in context: The cross-level moderating role of collective efficacy. Journal of Organizational Behavior, 32, 65-85.

Tennenbaum, G., \& Eklund, R. C. (2007). Handbook of sport psychology ( $3^{\text {rd }}$ ed.). New York, NY: Wiley.

Terracciano, A., Balaci, L., Thayer, J., Scally, M., Kokinos, S., Ferrucci, L., ... Costa, P. T. (2009). Variants of the serotonin transporter gene and NEO-PI-R neuroticism: No association in the BLSA and SardiNIA samples. American Journal of Medical Genetics B - Neuropsychiatric Genetics, 150B(8), 1070-1077.

Terracciano, A., McCrae, R. R., \& Costa, P. T. (2010). Intra-individual change in personality stability and age. Journal of Research in Personality, 44(1), 31-37.

Thune, J. B. (1949). Personality of weightlifters. Research Quarterly, 20(3), 296-306.

Tok, S. (2011). The big five personality traits and risky sport participation. Social Behavior and Personality, 39(8), 1105-1112.

Trninić, V., Baranciić, M., \& Nazor, M. (2008). The five-factor model of personality and aggressiveness in prisoners and athletes. Kinesiology, 40(2), 170-181.

Van Vianen, A. E. M., \& De Dreu, C. K. W. (2001). Personality in teams: Its relationship to social cohesion, task cohesion, and team performance. European Journal of Work and Organizational Psychology, 10(2), 97-120.

Vanden Auweele, Y., Nys, K., Rzewnicki, R., \& Van Mele, V. (2001). Personality and the athlete. In R. N. Singer, H. A. Hausenblas, \& C. M. Janelle (Eds.), Handbook of sport psychology ( $2^{\text {nd }}$ ed., pp. 239-268). New York, NY: Wiley.

Vealey, R. S. (2002). Personality and sport behavior. In T. Horn (Ed.), Advances in sport psychology ( $2^{\text {nd }}$ ed., pp. 43-82). Champaign, IL: Human Kinetics. 
Weinberg, R. S., \& Gould, D. (2011). Foundations of sport and exercise psychology $\left(5^{\text {th }}\right.$ ed.). Champaign, IL: Human Kinetics.

Williams, J. M. (1980). Personality characteristics of the successful female athlete. In W. F. Straub (Ed.), Sport psychology: An analysis of athlete behavior ( $2^{\text {nd }}$ ed., pp. 353-359). Ithaca, NY: Mouvement Publications.

Williams, L. R., \& Parkin, W. A. (1980). Personality factor profiles of three hockey groups. International Journal of Sport Psychology, 11(2), 113-120.

Woodman, T., Davis, P. A., Hardy, L., Callow, N., Glasscock, I., \& Yuill-Proctor, J. (2009). Emotions and sport performance: An exploration of happiness, hope, and anger. Journal of Sport and Exercise Psychology, 31, 169-188.

Woodman, T., Zourbanos, N., Hardy, L., Beattie, S., \& McQuillan, A. (2010). Do performance strategies moderate the relationship between personality and training behaviors? An exploratory study. Journal of Applied Sport Psychology, 22, 183-197. 